dose rather than malnutrition in the children. ${ }^{6}$ Vaccination gives substantial protection, reducing child mortality from the age of vaccination by at least $30 \% .^{7} \mathrm{~A}$ big difficulty in many countries is that up to the present measles immunisation cannot be given to children aged under 9 months. The World Health Organisation recommends, however, that in 1990 a high titre of the more immunogenic Edmonston-Zagreb vaccine should be made available. This concentrated vaccine will overcome residual maternal antibodies and may be used at the age of 6 months. ${ }^{8}$ Unicef hopes to have supplies available for sub-Saharan Africa by the middle of 1990 .

What about other new vaccines? All the vaccines available were already in use as long ago as 1974. There are many exciting potentials for the improvement of existing vaccines and new vaccines against major killer diseases, but resources for the development of new vaccines are limited. Many countries allot half of their research resources to the military. Can we hope that a proportion of this could be deflected to research on saving children's lives? Even then, particularly at this time of year, we need to consider the saying, "The difference between children and adults is the size and complexity of the toys they play with." World wide there is an unholy alliance between the developers of adult toys and their manufacturers and the medical profession, and it is this that absorbs so much research money. In Britain we suffer from vociferous pressure groups wanting investment in a $£ 10$ million cyclotron, though there are grave doubts over its medical value and a cost benefit analysis that would be absurd. ${ }^{9}$ Such monetary resources could save the lives of thousands of children.

Emeritus Professor of Tropical Child Health,

DAVID MORLEY

University of London,

Institute of Child Health,

London WCIN 1EH

1 Unicef. State of the world's children. Oxford: Oxford University Press, 1989.

2 Burki SJ, Voorhoeve JJC, Layton R, et al. Global estimates for meeting basic needs. Washington DC: World Bank, 1977

3 World Health Organisation. Expanded programme of immunisation. Geneva: World Health Organisation, 1989. (Progress and Evaluation Report A42/10.)

4 World Bank. Sub-Saharan Africa from crisis to sustainable growth. Washington DC: World Bank, 1989.

5 Unicef. State of the world's children. Oxford: Oxford University Press, 1985.

6 Morley DC, Aaby P. Severe measles: a new understanding. Medical Digest 1970;14:4-6.

7 Aaby P, Pedersen IB, Knudsen K, et al. Child mortality related to seroconversion or lack of seroconversion after measles vaccination. Paediatr Infect Dis 1989;8:197-200.

8 Khanum S, Uddin N, Garelick H, Mann G, Tomkins A. Comparison of Edmondston-Zagreb and Schwarz strains of measles vaccines given by aerosol or subcutaneous injection. Lancet 1987; $151-3$.

9 Tobias JS. The cyclotron saga continues. Br Med f 1989;299:1294-5.

\section{On the state of the public health}

\section{Thought provoking and readable-at last}

Most years since 1856 the chief medical officer of the Department of Health has produced an annual report-documents of variable style, content, and value. When Sir Donald Acheson became chief medical officer in 1984 he reviewed past reports, talked to colleagues, and set about making his annual accounts of the nation's health "an unbiased record of topical events relating to health and a commentary on progress and on important unsolved problems."

The latest report achieves these aims and does so in a style that encourages doctors who dip their noses into the pages to read on. ${ }^{2}$ Necessarily, much of the comment deals with events no longer in the headlines - but it is helpful and reassuring to have verdicts on aluminium in drinking water (no cause for immediate concern) and on the risks of listeriosis for the average healthy citizen (very small indeed). There are masses of data on health statistics, including international comparisons that show England and Wales well down the league table for infant mortality but close to the leaders for life expectancy. The report refers repeatedly to geographical variations in disease and mortality within England and Wales but makes little mention of social class differences in adultsyet these are very substantial: the gap between the rich and poor is as wide in health as it is in other more obvious features of lifestyle. Each year Sir Donald has one chapter focused on a particular aspect of health. This year it was the health of children. May we suggest another topic for next year-the health of the poor?

Deputy Editor, $B M \mathcal{F}$

TONY SMITH

1 Department of Health and Social Security. On the state of the public health for the year 1986. London HMSO, 1987.

2 Department of Health and Social Security. On the state of the public health for the year 1988. London: HMSO, 1989.

\section{Pay in the public sector}

\section{More review bodies needed}

The tenacity with which ambulance workers in Britain are pursuing their pay dispute this winter is scarcely surprising: together with several other public sector employees they have had a raw deal under the current administration. Ten years ago the distribution of pay in Britain was much more equal than it is now. In 1979 someone $10 \%$ from the bottom of the pay distribution received around half the pay of someone $10 \%$ from the top. Today that same person on a low wage earns only one third the amount at the top end of the scale. Many public servants have clearly been the losers in such a change.

For most employees in the public sector the 1980s have seen a decline in their pay relative to private earnings - in some cases (teachers, soldiers, and health service ancillaries) aggravating a trend begun in the 1970s. The modest increases in real wages received by these groups look meagre in comparison with those awarded in the private sector.

Wishful thinking by governments cannot ignore the fact that managers in the public sector have to accept influences from the private sector on the pay of their employees. Whether employers cite "labour market" factors as key determinants of pay or unions plead notions of equity, in effect both are arguing on the basis of comparability. And both know that public servants are increasingly losing that race.

For those at the bottom of the public sector pay league it is cold comfort to know that most of them do not fall within any standard definition of low pay: only women employed in the NHS as domestics can claim this dubious distinction. None the less, real wages have been shoved downwards as cash limited NHS managers have held down the pay of manual workers to fund unexpectedly high increases for nurses. Another factor in the NHS and in local government has been the adverse effect on earnings caused by compulsory competitive tendering for certain services. Higher productivity has been demanded, and crucial sources of additional income such as overtime have been removed. In many cases savings have been made - at the expense of filthy hospitals and roads and in the quality of other services.

Not only the less skilled have lost out. Public sector top 